Dr. sc. Sanja Grbić ${ }^{1}$, docentica

Pravni fakultet Sveučilišta u Rijeci

Dr. sc. Dejan Bodul2 ${ }^{2}$ docent

Pravni fakultet Sveučilišta u Rijeci

\title{
(NEFUNKCIONALAN) INSTITUCIONALNI OKVIR I PROBLEMI OSTVARIVANJA PRAVA NA PRAVIČNO SUĐENJE
}

$U D K: 341.347 .342$

Primljeno: 1. VI. 2018.

Izvorni znanstveni rad

Predstečajni postupci su, po svojoj prirodi i zakonskim propisima, postupci in exstremis u cilju očuvanja vrijednosti sredstava i zaštite interesa vjerovnika. Ipak, vrijeme potrebito za otvaranje predstečajnog postupka dulje je od zakonom predviđenih rokova. Stoga unatoč kvalitetno postavljenom normativnom okviru, problemi koji onemogućavaju učinkovitiji predstečajni postupak nisu oni vezani uz tekst zakona i pratećih propisa, već se nalaze u primjeni i/ili izvan samog predstečajnog pravnog okvira. Autori postavljaju tezu - kako reforma predstečajne nagodbe koja je rezultirala predstečajnim postupkom nije bila višestrana - činjenicom da zakonodavac nije predvidio učinke i posljedice koje će zakonske izmjene proizvesti te uslijed toga nije niti pripremio (pravosudni) sustav da ih spremno dočeka. Kompleksnost predmeta istraživanja i postavljeni zadaci uvjetovali su izbor metoda pa je u istraživanju prvenstveno korišten normativno-pravni metodološki pristup. U radu će se analizirati i praksa Europskog suda za ljudska prava u postupcima uz članak 6. jer polazimo od pretpostavke da saznanja o ovome mogu biti ključna za razumijevanje problematike rada.

Ključne riječi: ustavna i konvencijska počela, predstečajni postupak, rok za otvaranje

1. Okvir za raspravu; 2. Postavljanje problema; 3. Pravo na pošteno suđenje prema članku 6. Europske konvencije za zaštitu ljudskih prava i temeljnih sloboda ; 3.1. Građanska prava i obveze prema članku 6. EKLJP-a i stečajni postupci; 3.2. Pravo na pošteno suđenje u razumnom roku; 3.2.1. Ponašanje nadležnih vlasti; 3.2.2. Važnost predmeta spora za podnositelja; 4. Zaključna razmatranja

1 Katedra za teoriju prava i države, filozofiju prava, ljudska prava i javnu politiku, Pravni fakultet Sveučilišta u Rijeci, sgrbic@pravri.hr,091/536-3436.

2 Katedra za građansko postupovno pravo, Pravni fakultet Sveučilišta u Rijeci, dbodul@ pravri.hr, 091/544-1212.

Ovaj rad nastao je uz potporu Hrvatske zaklade za znanost u okviru projekta 6558 Business and Personal Insolvency - the Ways to Overcome Excessive Indebtednes. 


\section{OKVIR ZA RASPRAVU}

Iako je donošenjem Zakona o financijskom poslovanju i predstečajnoj nagodbi, ${ }^{3}$ 2012. znatno izmijenjen stečajni postupak u Republici Hrvatskoj, u njegovoj višegodišnjoj praktičnoj primjeni uočeno je niz problema u tumačenju i učincima pojedinih odredbi i instituta, što će se pokušati otkloniti donošenjem novog Stečajnog zakona ${ }^{4}$ Novi Stečajni zakon stupio je na snagu 1. rujna 2015. Svakako smatramo bitnim istaknuti kako prostor koji ovdje imamo ne dopušta detaljnu raščlambu ove problematike, pa smo prinuđeni ograničiti se isključivo, po mišljenju autora, na neke aspekte nove stečajne regulative. Najvažnije novine su članci Glave II. prema kojima odredbe o predstečajnoj nagodbi prelaze iz ZFPPN-a u SZ kao predstečajni postupak (dalje: PP) sukladno kojima bi FINA ostala tijelo predstečajnog postupka koje samo tehnički i administrativno pomaže sudu. Dakle, tijela PP-a su sudac pojedinac i povjerenik. Pritisak za ovakve reforme, odnosno za jaču ulogu suda u predstečajnim nagodbama, vršila je i primjena čl. 6. iz Europske konvencije za zaštitu ljudskih prava i temeljnih sloboda. ${ }^{5} \mathrm{U}$ gotovo dvije godine primjene SZ-a pokazuje se kako je broj pokrenutih predstečajnih postupaka relativno mali (273 pokrenuta postupka), pri čemu je u samo 58 slučajeva prihvaćen plan restrukturiranja i potvrđen predstečajni sporazum. ${ }^{6}$

Polazeći od cilja predstečajnog postupka propisanog SZ-om, a to je uređivanje pravnoga položaja dužnika i njegova odnosa prema vjerovnicima i održavanje njegove djelatnosti, u praksi se u svakoj fazi tog postupka nailazilo na niz problema u provedbi te spornih pravnih pitanja o kojima ovisi daljnji tijek postupka i ostvarivanje navedenog cilja postupka. Stoga je cilj Zakona o izmjenama i dopunama Stečajnog zakona, koji je stupio na snagu 2. studenoga 2017., primarno olakšati predstečajni postupak propisivanjem realnih rokova za poduzimanje određenih radnji u postupku. Spuštajući se na praktičnu i empirijsku razinu vidimo da, iako novo stečajno zakonodavstvo sadrži značajan broj novih instituta i mehanizama, može se reći da nije došlo do značajnije konceptualne promjene, tako da ne bi trebalo doći do većih problema u primjeni prava. Paralelno s promjenama stečajnog okvira uređen je i Zakon o trgovačkim društvima, ${ }^{7}$ a izvršena je i reforma ovršnog postupka ${ }^{8}$ Time se

3 NN, br. 108/12, 144/12, 81/13 i 112/13 (71/15 i 78/15) - dalje ZFPPN.

4 Stupanjem na snagu novog SZ-a (NN, br. 71/15 i 104/17) prestaje važiti Stečajni zakon, NN, br. 44/96, 29/99, 129/00, 123/03, 82/06, 116/10, 25/12, 133/12, 45/13, dalje: stari SZ. Također danom stupanja na snagu novog SZ-a u ZFPPN-u prestaje važiti odredba čl. 1., t. 3., odredbe čl. 3., t. 10., 11., 12, 14. i 15., čl. 17., st. 7., čl. 88., st. 1., t. 3. - 6. te čl. 18. - 86., dakle odredbe o predstečajnoj nagodbi.

5 NN-MU, br. 18/97, 6/99, 14/02, 13/03, 9/05, 1/06. i 2/10. - dalje: Konvencija ili EKLJP.

6 Izvor: Ministarstvo pravosuđa, Prijedlog izmjena Stečajnog zakona, Zagreb, 2017.

7 NN, br. 111/93, 34/99, 121/99, 52/00, 118/03, 107/07, 146/08, 137/09, 125/11, 152/11, 111/12, $68 / 13,110 / 15$. Od recentnih izmjena istaknuli bismo zakonske preduvjete za smanjenje troškova likvidacije društva s ograničenom odgovornošću te pojednostavljenje postupka likvidacije za sva društva kapitala.

8 NN, br. 112/12, 25/13, 93/14, 55/16, 73/17. Najvažnije promjene u ovrsi na nekretnini iz Novele 2017 odnose se na: zaštitu ovršenika fizičke osobe; posebne uvjete za određivanje ovrhe na nekretnini; odgodu ovrhe; položaj ovršenika kao najmoprimca te stambeno zbrinjavanje ovršenika. 
formirao zaokruženi pravni okvir koji treba omogućiti ili restrukturiranje dužnika ili učinkovit izlazak s tržišta. ${ }^{9}$ Ipak, uspješnost reformi se iskazuje i činjenicom prema kojoj se moderna i učinkovita tržišna gospodarstva ne mogu zamisliti bez suvremeno organiziranog i funkcionalnog sustava sudova i pratećih tijela. Analizirajući cjelokupni hrvatski stečajni sustav i sustav organiziranja trgovačkih sudova, vidimo da su u 2015. zaprimili 19.543 stečajna predmeta, a riješili samo 5255, što predstavlja svega 26,9 \% riješenih predmeta u odnosu na primljene. Opterećenost sudaca u tim predmetima povećala se na 1651 predmet po sucu, što na neki način otkriva razloge povećanja zaostataka. ${ }^{10}$ Analizirajući statističke podatke iz 2016. i 2017. u pogledu brojčanog stanja zaprimljenih predmeta, riješenih predmeta kao i opterećenosti sudaca, situacija je uvelike identična. Autori su stoga mišljenja kako je navedeno posljedica novoga SZ-a, ali i izmjena SZ 2017. Pri tome se očekuje daljnji rast priljeva stečajnih predmeta što je izravna posljedica zatečenog stanja, novog SZ-a i njegovih izmjena. ${ }^{11}$ Stoga je potrebno žurno poduzeti korektivne mjere kako bi se trgovački sudovi, u razumnim rokovima, mogli nositi s ovako povećanim priljevom predmeta. To je zapravo i najveći nedostatak SZ-a, tj., ograničenost institucionalnog kapaciteta za provođenje (pred)stečajnih postupaka, u prvom redu „stečajnih“ sudova (stečajnih sudaca) i stečajnih upravitelja.

\section{POSTAVLJANJE PROBLEMA}

Stečajni zakon stvara poticaje, prije svega financijski problematičnim subjektima, kako bi se žurno i pravovremeno pokrenuo predstečajni postupak radi redefiniranja poslovnih odnosa. Stoga članak 31. SZ-a propisuje da je sud, ,dužan odlučiti o prijedlogu za otvaranje predstečajnoga postupka u roku od osam dana od dana podnošenja potpunoga prijedloga". Ipak ovako formuliran rok postavlja strankama zadatak da osiguraju da sud unutar toga roka donese odluku o podnesenom prijedlogu, što se u praksi čini otežanim imajući na umu spomenutu opterećenost trgovačkih sudova, jer ako sudovi u praksi budu odlučivali o prijedlozima izvan postavljenog roka od 8 dana (koji je Visoki trgovački sud ocijenio - instruktivnim), ${ }^{12}$ doći će se

9 Vidi, Bodul, D., „Pluralitet ciljeva stečajnog postupka“, Zbornik radova Pravnog fakulteta u Splitu, vol. 54, 2017., br. 3, str. 587-613.

10 Tako i podrobnije, Turkalj, K., „Kako pravosuđe može dati doprinos gospodarskom rastu u Republici Hrvatskoj“, Pravo i porezi, 2016., br. 4, str. 59. et seq.

11 Exempli causa, ne smije se izgubiti iz vida da su trgovački sudovi, sukladno odredbama novog SZ-a, postali i „ovršni“ sudovi. Naime, kako je u praksi uočeno da ovršni postupci koje pokreću i vode razlučni vjerovnici dugo traju, što produljuje trajanje stečaja, ukinuto je pravo razlučnog vjerovnika da nakon otvaranja stečaja pokreće ovršne postupke te je određeno da će se svi ovršni postupci koje vode razlučni vjerovnici nakon otvaranja stečajnog postupka prekinuti i uputiti pred trgovačke sudove (čl. 169., st. 6. SZ-a) pa je za pretpostaviti da će sve u konačnici rezultirati i sporovima pred višim sudovima, što će dodatno opteretiti sustav trgovačkog pravosuđenja i postaviti pitanje postizanja standarda „razumnog roka" provođenja stečajnih postupaka.

12 Rješenje Visokog trgovačkog suda Republike Hrvatske broj Pž-433/16 od 8. ožujka 2016. 
Dr. sc. Sanja Grbić i dr. sc. Dejan Bodul: (Nefunkcionalan) institucionalni okvir i problemi... Zbornik radova Pravnog fakulteta u Splitu, god. 55, 4/2018., str. 755.- 769.

u situaciju da isključivo mogu konstatirati postojanje stečajnih razloga. ${ }^{13}$ Naravno, treba uzeti u obzir da na takve podatke, pored samih zakonskih rješenja, utječu i brojni izvansudski (institucionalni) čimbenici (zatečeni broj predmeta, nedovoljan broj sudaca kojima je bilo povjereno vođenje stečajnog postupka, slaba obučenost stečajnih upravitelja, neadekvatni način njihova financiranja i posljedično slaba motiviranost za rad).

Dakle, analizirajući je li konkretna nacionalna zakonska norma primijenjena na adekvatan način, sasvim je legitimno, a s praktičnog aspekta opravdano i korisno, analizirati praksu Europskog suda za ljudska prava (dalje: ESLJP) u postupcima po čl. 6. (Pravo na pravično suđenje). Namjera je da se razjašnjavanjem pravnih instituta koji su nastali kao rezultat dugogodišnje prakse ESLJP-a i sagledavanjem međusobnog odnosa s praksom hrvatskih trgovačkih sudova dođe do saznanja o pravno-logičkom mehanizmu odlučivanja ESLJP-a te uvidi predstavlja li nemogućnost pokretanja predstečajnog postupka u okviru zakonskog roka, zbog nedostatnog institucionalnog okvira, povredu prava na pravično suđenje.

13 U pogledu razloga za otvaranje predstečaja, sada je dužniku dan kratki rok u kojem može tražiti pokretanje ovog postupka. Naime, predstečajni postupak može se otvoriti ako sud utvrdi postojanje prijeteće nesposobnosti za plaćanje. Prijeteća nesposobnost za plaćanje postoji ako sud stekne uvjerenje da dužnik svoje postojeće obveze neće moći ispuniti po dospijeću, s time da presumpcija prijeteće nesposobnosti za plaćanje postoji kada mu je račun blokiran ili kada kasni dulje od 30 dana s isplatom plaće ili doprinosa prema plaći. Pravila o stečajnim razlozima su promijenjena na način da je ukinuta nelikvidnost kao stečajni razlog, a zakonodavac je ukinuo i mogućnost pokretanja stečajnog postupka ako postoji prijeteća nesposobnost za plaćanje. To se opravdava činjenicom da dužnik može u tom slučaju podnijeti prijedlog za predstečajnu nagodbu, ali kada je dužniku poznato da vjerovnici ne žele sklapanje predstečajne nagodbe, onda nema smisla tjerati dužnika u taj postupak. Stoga je sada određeno da su stečajni razlozi nesposobnost za plaćanje i prezaduženost. Nesposobnost za plaćanje postoji ako dužnik ne može trajnije ispunjavati svoje dospjele novčane obveze, a smatra se da je dužnik nesposoban za plaćanje ako u očevidniku ima neizvršene osnove za plaćanje dulje od 60 dana odnosno ako nije isplatio tri uzastopne plaće radnicima. Postojanje okolnosti blokade računa dokazuje se potvrdom FINA-e, a neisplate plaće radniku potvrdom Ministarstva financija - Porezne uprave. Prezaduženost postoji ako je imovina dužnika pravne osobe manja od postojećih obveza. U izmjenama SZ-a iz 2017. prijeteća nesposobnost za plaćanje ponovno je propisana kao stečajni razlog, čime se dopušta otvaranje stečajnog postupka i u razdoblju kada još nije nastupila trajnija nesposobnost za plaćanje ili prezaduženost dužnika. Prijeteća nesposobnost za plaćanje kao stečajni razlog dopuštena je samo kada dužnik predlaže otvaranje stečaja, s time da se na ovaj razlog odgovarajuće primjenjuju pravila o nesposobnosti za plaćanje kao predstečajnom razlogu. Iz obrazloženja prijedloga novele proizlazi da su razlozi zbog kojih se (ponovno) predlaže da prijeteća nesposobnost za plaćanje bude propisana kao stečajni razlog, kao prvo, kada dužnik nije spreman ili ne želi nastaviti s poslovanjem, a zna da će u jednom trenutku dospjeti obveze zbog kojih će postati trajnije nesposoban za plaćanje i zna da neće imati dovoljno imovine za namirenje svih vjerovnika, zbog čega se ne bi mogao uspješno provesti postupak likvidacije, onda bi bilo nerazumno tjerati ga $u$ predstečajni postupak ili ostaviti ga čekati da se ispuni jedan od stečajnih razloga. Osim toga, dopuštenje za otvaranje stečajnog postupka prije nastupanja stečajnih razloga jest prilika da se restrukturiranje ostvari kroz stečajni plan, u kojem slučaju dužnik više neće voditi poslove društva (vođenje društva prepušta se stečajnom upravitelju). 


\section{PRAVO NA POŠTENO SUĐENJE PREMA ČLANKU 6. EUROPSKE KONVENCIJE ZA ZAŠTITU LJUDSKIH PRAVA I TEMELJNIH SLOBODA}

Pravo na pošteno suđenje $\mathrm{e}^{14}$ temeljno je načelo vladavine prava u demokratskom društvu koje omogućuje pravično provođenje pravde. Stoga, suci, sudovi i tribunali država ugovornica EKLJP-a moraju postupati u skladu s pravima i načelima sadržanima u članku 6. kada odlučuju o građanskim i kaznenim predmetima. Ono je jedno od najvažnijih i središnjih prava prema EKLJP-u. Ujedno je i pravo u odnosu na koje je podneseno najviše zahtjeva ESLJP-a, te utvrđeno i najviše povreda. Zbog tako opsežne sudske prakse, ESLJP je u detalje razradio prava i načela koja donosi ovaj članak uvodeći i neka nova prava koja nisu izvorno sadržana u samom tekstu članka 6. Prava i načela koja ovaj članak sadrži možemo podijeliti u tri skupine, a to su pravo na pristup sudu, pravo na postupak odgovarajuće kvalitete i pravo na zakonom ustanovljeni, nezavisan i nepristran sud. Pravo na postupak odgovarajuće kvalitete podrazumijeva i pravo na pošteno suđenje u razumnom roku koje je od velike važnosti za Republiku Hrvatsku, te pravo na čiji je razvoj i zaštitu uvelike utjecala i sudska praksa ESLJP-a. Budući da je duljina trajanja postupaka veliki problem hrvatskog pravosuđa, u ovom dijelu rada osvrnut ćemo se na duljinu trajanja stečajnih postupaka i relevantnu sudsku praksu ESLJP-a koju je potrebno uzeti u obzir prilikom rješavanja ovog značajnog problema hrvatskog pravosuđa, napose stečajnih postupaka i njihove pravne regulacije u hrvatskom pravnom sustavu.

\subsection{Građanska prava i obveze prema članku 6. EKLJP-a i stečajni postupci}

Članak 6. jamči svakome pravo na pošteno suđenje prilikom utvrđivanja prava i obveza građanske naravi ili u slučaju podizanja optužnice za kazneno djelo. ${ }^{15}$ Kako bi se sva prava i načela poštenog suđenja mogla ostvariti i zajamčiti podnositeljima zahtjeva potrebno je da se njihov predmet može podvesti pod građanska prava i obveze. Građanska prava i obveze autonomni su pojmovi što znači da ih ESLJP tumači, objašnjava ili definira kroz svoju sudsku praksu, neovisno o njihovu značenju i primjeni u nacionalnim pravnim sustavima država ugovornica EKLJP-a. Ovdje je potrebno istaknuti kako ESLJP nije svojom sudskom praksom stvorio definiciju građanskih prava i obveza, već je odredio posebne kriterije prema kojima se može tvrditi potpada li ili ne predmet pod građanska prava i obveze. Stoga cee sva prava i načela koja donosi članak 6. ispitivati ESLJP samo ako se predmeti o

14 EKLJP, čl. 6., st. 1.: „Radi utvrđivanja svojih prava i obveza građanske naravi ili u slučaju podizanja optužnice za kazneno djelo protiv njega svatko ima pravo da zakonom ustanovljeni nezavisni i nepristrani sud pravično, javno i u razumnom roku ispita njegov slučaj. (...)"

15 Vidi više Grbić, S., „Građanska prava i obveze kao autonomni pojmovi prema čl. 6 Europske konvencije za zaštitu ljudskih prava i temeljnih sloboda“, Pravni vjesnik Pravnog fakulteta Sveučilišta Josipa Jurja Strossmayera u Osijeku, god. 28, br. 3-4, 2012., str. 117-146. 
kojima se raspravlja mogu podvesti pod građanska prava i obveze. Ti kriteriji ovise o okolnostima svakog pojedinog predmeta koji dođe pred ESLJP. Danas ESLJP podvodi veliki broj prava pod građanska prava, koja se prema nacionalnim pravima država ugovornica EKLJP-a ne smatraju takvima.

U odluci S.p.r.l. ANCA i ostali protiv Belgije ${ }^{16}$ ESLJP je još 1984. godine utvrdio da je primjenjivost članka 6 . na stečajni postupak neupitna te da on potpada pod pojam građanskih prava i obveza. ${ }^{17} \mathrm{U}$ odluci o dopuštenosti Bačić protiv Hrvatske ${ }^{18}$ ESLJP je isto potvrdio i za stečajne postupke koji se vode u Republici Hrvatskoj. Tu je utvrdio da je u ovome predmetu utvrđivanje građanskih prava i obveza prema članku 6. započelo u građanskome postupku koji je podnositeljica vodila protiv bivšeg poslodavca, osporavajući odluku o prestanku radnog odnosa i tražila isplatu plaća za razdoblje u kojemu je bila bez posla, a nastavilo se u stečajnome postupku vođenom protiv podnositeljičina bivšeg poslodavca u kojemu je podnositeljica bila jedan od vjerovnika. Zaključno, ESLJP je utvrdio kako se prema članku 6. EKLJP-a građanski i stečajni postupak uzimaju kao jedna cjelina. ${ }^{19}$

\subsection{Pravo na pošteno suđenje u razumnom roku}

Budući da je primjena članka 6. na stečajne postupke neupitna za potrebe ovoga rada, dalje ćemo razmatrati sudsku praksu ESLJP-a koja se odnosi na razumni rok trajanja stečajnih postupaka. Prvo, treba istaknuti kako se razlozi zbog kojih se najčešće poziva na povredu članka 6 . EKLJP-a, odnose na duljinu trajanja postupaka, tj. pravo na pošteno suđenje $u$ razumnom roku. Zbog toga je i ovdje praksa ESLJP-a vrlo opsežna te je donesen daleko najveći broj presuda nego li u odnosu na bilo koje drugo pravo iz EKLJP-a. Podnositelji se zbog povrede razumnog roka mogu obraćati ESLJP-u bilo tijekom trajanja postupka za koji smatraju da predugo traje ili nakon završenog postupka, u potonjem slučaju u roku od šest mjeseci nakon donošenja pravomoćne odluke. Tako je kroz ovu opsežnu sudsku praksu ESLJP stvorio kriterije koje uvijek ispituje kada utvrđuje je li došlo do povrede razumnog roka. Iz toga proizlazi zaključak kako možemo reći da je postupak pošten prema članku 6. EKLJP-a samo ako je, između ostalog, proveden u razumnom roku. U skladu s time, u predmetu Zimmermann i Steiner protiv Švicarske utvrđeni su sljedeći kriteriji za određivanje je li postupak trajao preko razumnog roka:

„Razumni rok, u okviru kojeg se mora provesti postupak i koji potpada pod članak 6., stavak 1. EKLJP-a, mora se odrediti u svakom pojedinom slučaju prema okolnostima toga predmeta. ESLJP mora uzeti u obzir složenost činjeničnih i

16 S.p.r.l. ANCA i ostali protiv Belgije, odluka, 10. prosinca 1984., br. 10259/83.

17 Vidi i Interfina and Christian della Faille d'Huysse protiv Belgije, odluka, 4. svibnja 1987. br. 11101/84, Ceteroni protiv Italije, presuda, 15. studenoga 1996., br. 22461/93 i 22465/93, Bassani protiv Italije, presuda, 11. prosinca 2003., br. 47778/99 i Capital Bank AD protiv Bugarske, presuda, 24. studenoga 2005., br. 49429/99.

18 Bačić protiv Hrvatske, odluka, 19. lipnja 2008., br. 43595/06.

19 Vidi i Sukobljević protiv Hrvatske, presuda, 2. studenoga 2006., br. 5129/03 i LB Interfinanz A.G. protiv Hrvatske, presuda, 27. ožujka 2008., br. 29549/04. 
pravnih pitanja, ponašanje podnositelja i nadležnog tijela i značaj predmeta za podnositelja ...".

Konačno možemo reći da pri procjenjivanju razumnosti relevantnog razdoblja, ESLJP posebno razmatra sljedeće čimbenike:

1) složenost predmeta,

2) ponašanje podnositelja,

3) ponašanje nadležnih vlasti i

4) važnost predmeta spora za podnositelja.

ESLJP prilikom utvrđivanja razumnog roka trajanja postupaka u obzir uzima sve relevantne okolnosti svakog pojedinog predmeta o kojemu raspravlja. Tako je, primjerice, utvrdio kako dugotrajni postupci mogu zadovoljiti taj kriterij ako je predmet složen ili ako dugotrajnosti postupka nije pridonio podnositelj svojim ponašanjem, pa je u takvim situacijama utvrđeno da nije došlo do povrede razumnog roka. Nasuprot tomu, za postupke koji su trajali kraće vremensko razdoblje može se zaključiti da su ipak trajali nerazumno dugo, ako je u takvim predmetima došlo do velikih odugovlačenja za koja su bile odgovorne nadležne vlasti. U građanskim postupcima i stranke moraju pokazati dužnu pažnju u vođenju postupka, a samo za ona odugovlačenja za koja se državu može smatrati odgovornom, opravdano se može utvrditi da je prekoračen razumni rok. Stoga ne postoji točno određeni vremenski okvir za koji ESLJP uvijek utvrđuje je li došlo do povrede razumnog roka, već on to čini ispitujući sve relevantne okolnosti pojedinog predmeta o kojemu raspravlja i gore navedene kriterije utvrđene svojom sudskom praksom.

Nadalje će biti obrađena dva kriterija, ponašanje nadležnih vlasti i važnost predmeta spora za podnositelja jer su oni od presudne važnosti kada govorimo o duljini trajanja stečajnih postupaka, tj. oni su imali ključnu ulogu prilikom utvrđivanja povrede prava na suđenje u razumnom roku kada je ESLJP ispitivao duljinu trajanja stečajnih postupaka.

\subsubsection{Ponašanje nadležnih vlasti}

Pri ispitivanju povrede duljine trajanja postupka nastojanja sudskih vlasti da što brže provedu postupak vrlo su bitna. Tako na sudu leži posebna odgovornost osigurati da sve osobe u postupku daju maksimum kako bi se izbjegla nepotrebna kašnjenja. Svaka država smatra se odgovornom za svako nerazumno trajanje postupka koje se pripisuje njezinim sudskim i upravnim tijelima. Tu se matematički uzimaju u obzir razdoblja neaktivnosti sudova. Neaktivnost ne znači samo neodržavanje rasprave, već izostanak bilo kojih postupovnih radnji kroz dulje razdoblje. Takvo postupanje nadležnih vlasti ESLJP strogo sankcionira. ESLJP je posebno istaknuo i u više navrata u svojoj sudskoj praksi potvrdio kako na državama ugovornicama leži posebna odgovornost organizirati svoje pravosudne sustave na način da njihovi 
sudovi mogu ispuniti svaki od zahtjeva iz članka 6., posebice zahtjev za suđenje u razumnom roku. ${ }^{20}$

Kako bi se utvrdila takva odgovornost države, primjerice, ESLJP smatra da je država odgovorna ako puno vremena prođe pri ustupanju ili dostavi predmeta između sudova ili kada postoji nedostatak koordinacije između upravnih organa. Vođenje rasprave može, također, biti u suprotnosti sa zahtjevom suđenja u razumnom roku, ako je izvođenje dokaza predugo trajalo ili je bilo nepotrebno. Štoviše, ako je postupak odgođen jer se čekao ishod nekog drugog, paralelnog postupka, to također može predstavljati dovoljan razlog za odgovornost. U odgovornost države spadaju i kašnjenja za koja su odgovorna različita administrativna tijela. Ponekad su takva kašnjenja rezultat individualne odluke u pojedinom slučaju. Ona uključuju upućivanje predmeta s jednog suda na drugi, zajednička ročišta u predmetima protiv dvoje ili više optuženih, dostavljanje sudske odluke optuženoj strani i održavanje rasprava po žalbi i sl.

Državna tijela odgovorna su za kašnjenja onda kada odobre produženje rokova, a uslijed takvog produženja se ustanovi da je ono bilo nepotrebno. Tamo gdje je produženje rokova nužno, njih treba produžiti na način koji će dovesti do najkraćeg mogućeg odlaganja. Stoga, privremena obustava postupka radi donošenja odluke u drugom postupku u načelu je opravdana prema članku 6.

U razmatranju predmeta u odnosu na dužinu trajanja postupka, ESLJP je vodio računa o načelu ispravnog izvršenja pravde, što znači ispitivanje jesu li domaći sudovi u skladu sa svojom obvezom rješavali predmete koji su im dostavljeni. ${ }^{21}$ Tako su nastojanja sudskih vlasti za ubrzanjem postupaka vrlo značajna za osiguravanje prava podnositelja prema članku $6 .{ }^{22} \mathrm{Zbog}$ toga, posebna odgovornost leži na nacionalnim sudovima, a sastoji se u osiguravanju izbjegavanja nepotrebnog kašnjenja. ${ }^{23}$

Do kašnjenja može doći zbog nagomilavanja predmeta u sudovima. ESLJP je utvrdio da do takvog kašnjenja može doći zbog dva uzroka. Prvi obuhvaća hitne slučajeve, koji se javljaju primjerice u vrijeme recesije. ${ }^{24}$ Tada iznenada dolazi do velikog porasta pokretanja postupaka. Privremena opterećenost sudstva ne povlači automatski za sobom povredu prava na suđenje u razumnom roku, ako država brzo poduzme odgovarajuće mjere kojima bi takvo stanje zaustavila. ${ }^{25}$ Stoga, države ugovornice nisu odgovorne u slučaju privremenog zaostatka svojih sudova, pod uvjetom da odmah poduzmu mjere za uklanjanje nastale izvanredne situacije. Poduzete mjere moraju biti djelotvorne, a uz njihovu djelotvornost ESLJP ispituje

20 Vidi, Zavodnik protiv Slovenije, presuda, 21. svibnja 2015., br. 53723/13., Tusa protiv Italije, presuda, 27. veljače 1992., br. 13299/87 i Jama protiv Slovenije, presuda, 19. srpnja 2012., br. 48163/08.

21 Vidi, Ewing protiv Ujedinjenog Kraljevstva, odluka, 6. svibnja 1989., br. 14720/89.

22 Vernillo protiv Francuske, presuda, 20. veljače 1991., br. 11889/85.

23 Nuala, M., Harby, C., Pravo na pošteno suđenje, Sarajevo, IMETEC, 2005., str. 60.

24 Vidi, Buchholz protiv Savezne Republike Njemačke, presuda, 6. svibnja 1981., br. 7759/77.

25 Vidi npr. Milasi protiv Italije, presuda, 25. lipnja 1987., 10527/83. Isto to je ESLJP iznio u presudi Zimmermann i Steiner protiv Švicarske, presuda, 13. srpnja 1983., 8737/79. 
i njihovu pravodobnost. Zaključno, ESLJP je utvrdio da i djelotvorne mjere mogu dovesti do povrede razumnog roka duljine trajanja postupaka ukoliko nisu poduzete pravodobno. ESLJP prilikom odlučivanja o pravodobnosti i djelotvornosti mjera u obzir uzima političke i društvene prilike države koja navedene mjere donosi.

Druga vrsta uzroka je strukturalnog tipa, i javlja se kada se pojavljuje više predmeta nego što ih pravosudna tijela mogu riješiti. Tada se "manje važni" predmeti ostavljaju po strani, kako bi se riješili kritičniji, ili ukoliko država nije učinkovito uklonila nastalu izvanrednu situaciju. ESLJP je utvrdio da je tada neprimjereno svako produživanje postupaka izvan onoga što se može smatrati razumnim rokom. To se primjerice odnosi na slučaj kada do takvih kašnjenja dolazi ako previše vremena prođe do donošenja presude ili ako se odgađaju saslušanja zbog toga što suci rješavaju istodobno veliki broj predmeta, ${ }^{26}$ pa se preopterećenost sudstva općenito ne prihvaća kao opravdanje.

U predmetu Guincho protiv Portugala ${ }^{27}$ ESLJP je naveo razloge kojima je došao do gore navedenog stajališta. G. Guincho je doživio prometnu nesreću u Portugalu 1976. godine. Tražio je naknadu štete, ali taj je postupak trajao skoro četiri godine. Kada je podnio svoj zahtjev ESLJP-u žaleći se na duljinu postupka, Portugal je istaknuo kako je u to vrijeme pravosudni sustav Portugala djelovao u izvanrednim okolnostima: demokracija je ponovno uspostavljena tek 1974.; novoosnovane ustanove tek su se trebale uskladiti; oko milijun ljudi se doselilo iz bivših kolonija. Uz to, domaći su sudovi trebali steći povjerenje u doba velike ekonomske recesije. Poduzeto je nekoliko mjera kako bi pravosuđe moglo funkcionirati, ali u razdoblju između 1974. i 1979. broj podnesenih tužbi ipak se udvostručio. ESLJP je to prihvatio kao i činjenicu da "privremena preopterećenost sudova ne predstavlja, odmah, međunarodnu odgovornost države prema EKLJP-u, ako je ta država brzo poduzela učinkovite mjere za uklanjanje takve situacije". Međutim, ESLJP je podsjetio kako je ratifikacijom EKLJP-a Portugal prihvatio obvezu organiziranja svog pravosudnog sustava koji će biti u skladu sa zahtjevima iz članka 6., stavka 1., uključujući i obvezu provođenja postupaka u razumnom roku. Posebno je bila istaknuta važnost zahtjeva za pravilnim funkcioniranjem pravosudnog sustava. Nakon toga, ESLJP je ispitivao mjere koje je poduzeo Portugal da bi uklonio uzroke takve situacije i zaključio kako su one bile nedovoljne i provedene sa zakašnjenjem. UZ to, ESLJP je izričito zauzeo stajalište da nedostatak osoblja ili opća opterećenost upravnim stvarima ne može biti isprikom za nepridržavanje standarda razumnog roka. ${ }^{28}$

U predmetu Martins Moreira protiv Portugala ${ }^{29}$ ESLJP je utvrdio da se razna odlaganja mogu pripisati domaćim sudovima. Ona su uključivala i tromjesečni razmak između saslušanja podnositelja pred sudom i donošenja preliminarne odluke,

26 Janis, M., Kay., R., Bradely, A., European Human Rights Law, Text and materials, Oxford, Oxford University Press, 2008., str. 419.

27 Guincho protiv Portugala, presuda, 10. srpnja 1984., 8990/80.

28 Vidi npr. De Cubber protiv Belgije, presuda, 26. listopada 1984., Serija A, br. 86., Guincho protiv Portugala, presuda, 10. srpnja 1984., br. 8990/80.

29 Martins Moreira protiv Portugala, presuda, 26. listopada 1988., br. 11371/85. 
kao i četveromjesečno odlaganje zbog donošenja odluke o stručnom liječničkom mišljenju. Druga odlaganja odnosila su se na osmomjesečni razmak od trenutka kada je podnositelj uložio žalbu i datuma kada je taj predmet zaveden u registar žalbenog suda. ESLJP je utvrdio da su domaći sudovi opterećeni velikim brojem neriješenih predmeta, što predstavlja dio organizacijskog problema. Međutim utvrdio je i kako nije učinjeno ništa da se takvi problemi riješe. Drugi oblici kašnjenja proizašli su iz postupka koji se vodio zbog pribavljanja medicinskih izvještaja. Trebalo je dvije godine da se obave sva medicinska ispitivanja. Utvrdio je i da su domaći sudovi odgovorni i za ta kašnjenja, s obzirom na to da su medicinske ustanove javne i da one zbog nedostatka resursa nisu mogle brzo djelovati. U svakom slučaju sudovi snose opću odgovornost za ekspeditivnost u svim stadijima postupka. Temeljem toga, došlo je do povrede prava na pošteno suđenje u razumnom roku.

Nadalje, u predmetu Zimmermann $i$ Steiner protiv Švicarske ${ }^{30}$ ESLJP je utvrdio da je zadatak država da: „organiziraju svoje pravne sustave tako da omoguće sudovima poštovanje prava prema članku 6. uključujući i onaj o suđenju u razumnom roku“. U tom su predmetu prošle tri i pol godine prije nego što je žalbeni sud uzeo u razmatranje žalbu podnositelja. ESLJP je utvrdio da je žalbeni sud u to vrijeme bio preopterećen neriješenim predmetima. Nacionalne vlasti su to smatrale privremenim problemom i poduzele su neke mjere da se taj problem riješi. Međutim, dok je žalbeni sud shvatio da se radi o organizacijskom problemu i bio spreman poduzeti neophodne korake da se takva situacija ispravi, mjere koje je donijelo zakonodavno tijelo, izglasavanje odluke o povećanju broja sudaca s dvadeset i osam na trideset i broja tajnika suda i drugih djelatnika s dvadeset i četiri na dvadeset i osam, nisu bile dostatne za rješavanje problema. ESLJP je utvrdio da se broj predmeta povećao razmjerno povećanju broja parnica. Prema tomu, protek od tri i pol godine za rješavanje predmeta na žalbenom sudu bio je prema mišljenju ESLJP-a predug. Ponovio je i da je uzeo u obzir politički i socijalni kontekst odgovorne države. Stoga je došlo do povrede članka 6 . stavka $1 .{ }^{31}$

ESLJP je bio popustljiviji, pri ocjenjivanju tih kriterija, u predmetu Süßmann protiv Njemačke, ${ }^{32} \mathrm{u}$ kojem se podnositelj žalio na duljinu postupka pred njemačkim Saveznim ustavnim sudom. ESLJP je ovdje zaključio da nije došlo do povrede članka 6. jer sama uloga Ustavnog suda, kao čuvara ustavnog poretka, zahtijeva ponekad proučavanje i drugih čimbenika, npr. prirodu predmeta i njegovu važnost u političkom i socijalnom pogledu, a ne samo uobičajeni kronološki red kojim predmeti dolaze na listu toga suda. Nadalje, ESLJP je primijetio i kako je podnositeljeva žalba bila podnesena istodobno sa žalbama javnih djelatnika Demokratske Republike Njemačke koji su se žalili na odredbe Ugovora o njemačkom ujedinjenju, a koje su dovele do prekida ugovora o radu za preko 300.000 osoba. Uzimajući sve to u obzir, ESLJP je zaključio: „imajući na umu jedinstveni politički kontekst ujedinjenja

30 Zimmermann i Steiner protiv Švicarske, presuda, 13. srpnja 1983., br. 8737/79.

31 Grozev, Y., Sian, L., Vitkauskas D., „Right to a fair trail under the European Convention for Protection of Human Rights (Article 6)“", Manual for Lawyers, London, Interights, 2008., str. 55.

32 Süßmann protiv Njemačke, presuda, 16. rujna 1996., br. 20024/92. 
Njemačke i ozbiljne socijalne posljedice koje su proizašle iz okončanja ugovora o radu, Savezni Ustavni sud je opravdano dao prioritet tim slučajevima“. Iz toga je vidljivo kako je do toga zaključka došlo zbog posebnog položaja ustavnih sudova, pa možemo reći kako je primjena članka 6 . na ustavne sudove uvijek podložna određenom stupnju rasprave. ${ }^{33}$

\subsubsection{Važnost predmeta spora za podnositelja}

Sljedeći kriterij koji ispituje ESLJP pri ocjenjivanju je li povrijeđeno pravo na pošteno suđenje u razumnom roku prema članku 6. EKLJP-a jest važnost predmeta spora za podnositelja, Tako, kada je riječ o određenim pitanjima, Europski sud mora postupati s još više pažnje i učinkovitije. U predmetu $H$. protiv Ujedinjenog Kraljevstva ${ }^{34}$ Europski sud je zaključio: „U predmetima u kojima se raspravlja o egzistencijalnim pitanjima za podnositelja, nadležne vlasti moraju postupati s dužnom pažnjom ... tu uvijek postoji opasnost da će postupovne odgode dovesti do rješavanja pitanja povodom kojeg je pokrenut postupak, prije nego što domaći sud, uopće, uspije održati raspravu o njemu“. ${ }^{35}$

To je potvrđeno u predmetima u kojima se raspravljalo o obiteljskim odnosima (primjerice, Bock protiv Savezne Republike Njemačke), ${ }^{36}$ starateljskim odnosima (navedeni predmet $H$. protiv Ujedinjenog Kraljevstva). Tu je značajan i predmet Hokkanen protiv Finske ${ }^{37}$ u kojemu je Europski sud zaključio da je „osnovno da se predmeti koji se odnose na starateljstvo rješavaju brzo " kao i u radnim odnosima. ${ }^{38}$ Tu spadaju i sporovi vezani uz mirovinu, osobito ako je podnositelj poodmakle dobi. Nadalje, u slučajevima u kojima su osobe zaražene virusom side transfuzijom krvi, u bolnicama kao što je to bilo u predmetu X protiv Francuske ${ }^{39}$ Također i u slučaju prometnih nesreća. ${ }^{40} \mathrm{U}$ tu kategoriju spadaju, zatim, predmeti u kojima se raspravlja o građanskom statusu i položaju, ${ }^{41}$ tj. statusni predmeti, a i stečajni postupci kao što je to potvrđeno u predmetu Zavodnik protiv Slovenije. ${ }^{42}$

\section{ZAKLJUČNA RAZMATRANJA}

33 Vidi, npr., Buchholz protiv Savezne Republike Njemačke, presuda, 6. svibnja 1981., br. 7759/77.

34 H. protiv Ujedinjenog Kraljevstva, presuda, 8. srpnja 1987., br. 9580/81.

35 Van Dijk, P., et al., Teorija i praksa Evropske konvencije o ljudskim pravima, Sarajevo, Mueller, 2001., str. 420-421.

36 Bock protiv Savezne Republike Njemačke, presuda, 29. ožujka 1989., br. 11118/84.

37 Hokkanen protiv Finske, presuda, 23. rujna 1994., br. 19823/92.

38 Obermeier protiv Austrije, presuda, 28. lipnja 1990., br. 11761/85.

39 X. protiv Francuske, presuda, 31. ožujka 1992., Serija A, br. 18020/91.

40 Silva Pontes protiv Portugala, presuda, 23. ožujka 1994., br. 14940/89.

${ }^{41}$ Vidi, Bock protiv Savezne Republike Njemačke, presuda, 29. ožujka 1989., br. 11118/84.

42 Zavodnik protiv Slovenije, presuda, 21. svibnja 2015., br. 53723/13. 
Za izradu novog SZ-a analizirana su komparativna rješenja, iskustva stručnjaka i sudionika u stečajnom postupku (stečajni suci, stečajni upravitelji, odvjetnici...) koji su primjenjivali stečajne propise, kao i statistika i drugi dostupni podaci vezani uz primjenu prethodnog zakona. Dakle, mišljenja smo kako je nova stečajna regulativa normativno kvalitetna u pogledu pravne sistematike, pravne tehnike i dosljednosti u normiranju čemu su svakako doprinijeli i trgovački sudovi kao stvarno nadležni za provođenje stečajnih postupaka. Ipak, analizirajući predmetnu problematiku iz perspektive ESLJP-a, vidljivo je da se isti načelno ne bavi načinom na koji su pojedine države članice odlučile urediti određeno područje. ESLJP smatra da država članica uživa „široko polje procjene“ na koji način će određeno pitanje urediti, imajući u vidu činjenicu da nacionalne vlasti najbolje poznaju svoju državu kao i ostale okolnosti od značaja za donošenje konkretnog zakona i da samim tim najbolje može procijeniti koje je zakonsko rešenje najadekvatnije. To je velika prednost koju uživaju nacionalne države, ali samim time i odgovornost za izbor najadekvatnijeg zakonskog rješenja. Ipak, kako je već rečeno, judikatura ESLJP-a obvezuje države ugovornice na organiziranje svojih pravosudnih sustava na način koji omogućava rad sudova u skladu sa zahtjevima iz čl. 6., st. 1., uključujući i zahtjev za vođenjem postupaka u „razumnom roku“. Privremena opterećenost sudstva ne utječe na tu obvezu države, ako one brzo poduzmu potrebne korake kojima bi riješile takve situacije. Prema tome, države ugovornice nisu odgovorne u slučaju privremenog zaostatka svojih sudova, pod uvjetom da odmah poduzmu radnje da se popravi takva izvanredna situacija. Poduzete mjere procjenjuju se u odnosu na njihovu djelotvornost, a procjenjuje se i jesu li poduzete pravodobno. ${ }^{43}$ Mjere poduzete kasnije ne mogu promijeniti činjenicu prekoračenja razumnog roka. Kada to procjenjuje, ESLJP je spreman uzeti u obzir političke i društvene prilike zemlje. ESLJP u takvim situacijama smatra da je neprimjereno svako produživanje postupaka izvan onoga što se može smatrati razumnim rokom. Tako je ESLJP smatrao kako do takvih kašnjenja dolazi ako previše vremena prođe do donošenja presude ili ako se odgađaju saslušanja zbog toga što suci rješavaju istodobno veliki broj predmeta, pa se preopterećenost sudstva općenito ne prihvaća kao opravdanje duljine postupka i dovodi do povrede prava na pošteno suđenje u razumnom roku zbog ponašanja nadležnih vlasti. ESLJP je ovdje istaknuo kako nastojanja sudske vlasti da što brže provedu postupak, imaju vrlo važnu ulogu. U tom smislu na sudu leži posebna dužnost osiguranja da sve osobe u postupku daju maksimum kako bi se izbjegla nepotrebna kašnjenja, jer država je odgovorna za svako trajanje postupka koje se pripisuje njezinim sudskim i upravnim tijelima. Tu se, gotovo matematički, uzimaju u obzir razdoblja neaktivnosti sudova. Neaktivnost ne znači samo neodržavanje rasprave, već izostanak bilo kojih postupovnih radnji kroz dulje razdoblje. Takvu pasivnost ESLJP strogo sankcionira. Stoga, prihvaćajući činjenicu da se preko ESLJP-a afirmira načelo precedentalnog prava i time sudske prakse kao formalnog izvora prava, što zahtijeva pojačanu pozornost u praćenju i tog izvora prava, ovo će istraživanje doprinijeti potpunijem i cjelovitijem sagledavanju nekih

43 Vidi, Guincho protiv Portugala, presuda, 10. srpnja 1984., br. 8990/80. 
pravnih pitanja koja se mogu postaviti prilikom revizije instituta predstečajnog postupka.

\section{Bibliografija}

Europska konvencija za zaštitu ljudskih prava i temeljnih sloboda, NN-MU, br. 18/97, 6/99, 14/02, 13/03, 9/05, 1/06. i 2/10.

Ovršni zakon, NN, br. 112/12, 25/13, 93/14, 55/16, 73/17.

Stečajni zakon, NN, br. 44/96, 29/99, 129/00, 123/03, 82/06, 116/10, 25/12, 133/12, $45 / 13$

Stečajni zakon, NN, br. 71/15 i 104/17.

Zakon o financijskom poslovanju i predstečajnoj nagodbi, NN, br. 108/12, 144/12, 81/13 i 112/13 (71/15 i 78/15).

Zakon o trgovačkim društvima, NN, br. 111/93, 34/99, 121/99, 52/00, 118/03, 107/07, 146/08, 137/09, 125/11, 152/11, 111/12, 68/13, 110/15.

Bodul, D., „Pluralitet ciljeva stečajnog postupka“, Zbornik radova Pravnog fakulteta u Splitu, vol. 54, 2017., br. 3, str. 587-613.

Grbić, S., „Građanska prava i obveze kao autonomni pojmovi prema čl. 6 Europske konvencije za zaštitu ljudskih prava i temeljnih sloboda", Pravni vjesnik Pravnog fakulteta Sveučilišta Josipa Jurja Strossmayera u Osijeku, god. 28, br. 3-4, 2012., str. 117-146.

Grozev, Y., Sian, L., Vitkauskas D., „Right to a fair trail under the European Convention for Protection of Human Rights (Article 6)“, Manual for Lawyers, London, Interights, 2008., str. 55.

Janis, M., Kay., R., Bradely, A., European Human Rights Law, Text and materials, Oxford, Oxford University Press, 2008., str. 419.

Ministarstvo pravosuđa, Prijedlog izmjena Stečajnog zakona, Zagreb, 2017.

Nuala, M., Harby, C., Pravo na pošteno suđenje, Sarajevo, IMETEC, 2005., str. 60.

Turkalj, K., „Kako pravosuđe može dati doprinos gospodarskom rastu u Republici Hrvatskoj“, Pravo i porezi, 2016., br. 4, str. 59. et seq.

Van Dijk, P., et al., Teorija i praksa Evropske konvencije o ljudskim pravima, Sarajevo, Mueller, 2001., str. 420-421.

Bačić protiv Hrvatske, odluka, 19. lipnja 2008., br. 43595/06.

Bassani protiv Italije, presuda, 11. prosinca 2003., br. 47778/99.

Bock protiv Savezne Republike Njemačke, presuda, 29. ožujka 1989., br. 11118/84.

Buchholz protiv Savezne Republike Njemačke, presuda, 6. svibnja 1981., br. 7759/77.

Capital Bank AD protiv Bugarske, presuda, 24. studenoga 2005., br. 49429/99. 
Ceteroni protiv Italije, presuda, 15. studenoga 1996., br. 22461/93 i 22465/93.

De Cubber protiv Belgije, presuda, 26. listopada 1984., Serija A, br. 86., Guincho protiv Portugala, presuda, 10. srpnja 1984., br. 8990/80.

Ewing protiv Ujedinjenog Kraljevstva, odluka, 6. svibnja 1989., br. 14720/89.

Guincho protiv Portugala, presuda, 10. srpnja 1984., 8990/80.

H. protiv Ujedinjenog Kraljevstva, presuda, 8. srpnja 1987., br. 9580/81.

Hokkanen protiv Finske, presuda, 23. rujna 1994., br. 19823/92.

Interfina and Christian della Faille d'Huysse protiv Belgije, odluka, 4. svibnja 1987. br. $11101 / 84$.

Jama protiv Slovenije, presuda, 19. srpnja 2012., br. 48163/08.

LB Interfinanz A.G. protiv Hrvatske, presuda, 27. ožujka 2008., br. 29549/04.

Martins Moreira protiv Portugala, presuda, 26. listopada 1988., br. 11371/85.

Milasi protiv Italije, presuda, 25. lipnja 1987., 10527/83.

Obermeier protiv Austrije, presuda, 28. lipnja 1990., br. 11761/85. 2016.

Rješenje Visokog trgovačkog suda Republike Hrvatske broj Pž-433/16 od 8. ožujka

S.p.r.l. ANCA i ostali protiv Belgije, odluka, 10. prosinca 1984, br. 10259/83.

Silva Pontes protiv Portugala, presuda, 23. ožujka 1994., br. 14940/89.

Sukobljević protiv Hrvatske, presuda, 2. studenoga 2006., br. 5129/03.

Süßmann protiv Njemačke, presuda, 16. rujna 1996., br. 20024/92.

Tusa protiv Italije, presuda, 27. veljače 1992., br. 13299/87.

Vernillo protiv Francuske, presuda, 20. veljače 1991., br. 11889/85.

X. protiv Francuske, presuda, 31. ožujka 1992., Serija A, br. 18020/91.

Zavodnik protiv Slovenije, presuda, 21. svibnja 2015., br. 53723/13.

Zimmermann i Steiner protiv Švicarske, presuda, 13. srpnja 1983., 8737/79. 


\section{(NON-FUNCTIONAL) INSTITUTIONAL FRAMEWORK AND PROBLEMS OF EXERCISING THE RIGHT TO A FAIR TRIAL}

Pre-bankruptcy proceedings are by their nature and legal regulations, procedures in exstremis in order to preserve the value of property and to protect the interests of various creditors. However, the time required for the initiation of the pre-bankruptcy proceeding is longer than the deadline prescribed by the law. Therefore, despite a well-established normative framework, problems that prevent a more effective pre-bankruptcy proceeding are not related to the text of the law and the accompanying regulations, but those are in application and/or outside the pre-bankruptcy legal framework itself. The authors argue - that the reform of the pre-bankruptcy agreement resulted in the pre-bankruptcy proceedings was not multifaceted - the fact remains that the legislator did not foresee the effects and consequences of the legislative changes and therefore did not even prepare a (judicial) system to welcome them readily. The complexity of the subject matter of the research and the set tasks required the choice of methods, so in the research the normative legal methodological approach was primarily used. The paper also analyzes the practice of the European Court of Human Rights in the proceedings under Article 6, since the authors are based on the assumption that knowledge of this can be crucial for understanding the main issues of this paper.

Key words: constitutional and conventional principles, pre-bankruptcy proceeding, initiation deadline 